Omni-Akuatika, 13 (1): 117-123, 2017
ISSN: 1858-3873 print / 2476-9347 online
Research Article

\title{
Water Quality Study for Grouper Mariculture in Divur Bay Dullah Island, Tual City
}

\author{
Daniel Djokosetiyanto ${ }^{1)}$, Henny Fitri nawati ${ }^{\left.{ }^{*}\right)}$, Machfud $^{3)}$, Achmad Fahrudin $^{4)}$ \\ 1) Departemen Budidaya Perairan Fakultas Perikanan dan IImu Kelautan Institut Pertanian Bogor \\ 2) Pengelolaan Sumberdaya Alam dan Lingkungan Sekolah Pascasarjana Institut Pertanian Bogor \\ ${ }^{3)}$ Departemen Teknologi Industri Pertanian Fakultas Teknologi Pertanian Institut Pertanian Bogor \\ ${ }^{4}$ Departemen Manajemen Sumberdaya Perairan Fakultas Perikanan dan IImu Kelautan \\ Institut Pertanian Bogor
}

${ }^{*}$ Corresponding author: hennyfitri23@yahoo.com

Received 5 March 2017; Accepted 3 May 2017; Available online 31 May 2017

\begin{abstract}
Water quality is one of the factors that determine the feasibility and success of the development of grouper mariculture. The objective of this research was to analyze water quality which was prepared for grouper mariculture. This research was carried out in Divur Bay, Dullah island of Tual City. The water quality parameters observed were including temperature, brightness, salinity, $\mathrm{pH}$, current velocity, depth, substrate type, DO, nitrate and phosphate in ten stations spread in Divur Bay. Water quality data were analyzed descriptively. The results showed that Divur Bay was feasible for the grouper culture development with a range of values of temperature, brightness, salinity, $\mathrm{pH}$, current velocity, depth, $\mathrm{DO}$, nitrate and phosphate obtained were $30-31^{\circ} \mathrm{C}$; $2.28-7.86 \mathrm{~m}$; $33-35 \mathrm{ppt}$; 7.7-8.1; $0.06-0.617 \mathrm{~m} / \mathrm{s} ; 2 . .28-18.58 \mathrm{~m} ; 3.7-4.8 \mathrm{ppm} ; 0.0015-0.219 \mathrm{ppm} ; 0.0076-0.0767 \mathrm{ppm}$.
\end{abstract}

Keywords: water quality, mariculture, grouper, Divur Bay

\section{Introduction}

Mariculture is an important activity that has resulted in nearly half the fish needs of the world and it will increase expectedly in upcoming years (IFPRI, 2003; Wijkstrom, 2003; Hishamunda et. al. , 2009;. Yulianto et. al., 2015). Increasing demand for fishes as food sources is due to community's increasing awareness about nutritional advantages of fish and fishery products for health and human intelligence. In addition, mariculture has the economic and social impact because of directly providing jobs and revenue for community while contributing indirectly in collecting taxes and balancing market (Hishamunda et. al., 2009;. Hishamunda and Ridler, 2006),

Mariculture is a part of aquaculture which has developed very quickly, especially in the remote and small area (Hishamunda, et. al., 2009), where one of them is Tual City in Maluku province. Mariculture potential land area in the city of Tual reached 7,524 ha. The largest island in Tual city is Dullah island with an area of $\pm 93.32 \mathrm{~km} 2$ and a population in
2014 was 74986 people (BPS Maluku Tenggara, 2015). One commodity that has been cultivated by Dullah island community was grouper aquaculture which belong to be economically important fish species and featured in the development of marine aquaculture in Indonesia (Ghani et. al., 2015; Sugama et. al., 1986 ; Kusumaningrum, 2015; Asaad et. al., 2010). Groupers marketed in living conditions have prices almost five times more expensive than dead/frozen ones (Direktorat Jenderal Perikanan Budidaya, 2011; Kusumaningrum, 2015).

Grouper mariculture is generally conducted in floating net cages (KJA) which is located in offshore waters (Ghani et. al., 2015; Hishamunda et. al., 2009). The success in developing grouper mariculture is really determined by the accuracy of site selection and waters feasibility as a place of cultivation (Mustafa et. al., 2011; Ghani et. al., 2015; Affan, 2010; Mukuan et. al., 2013), Determining the cultivation location where has been carried 
out by grouper aquaculture fishermen on Dullah island mostly using feeling or trial error only (Hartoko and Helmi, 2004), then it is not adequately optimal, and it emerges impacts on the environment due to the inappropriateness non-physical conditions such as market share, security and human resources (Affan, 2010; Raharjo, 2008). Therefore, a research on water quality become an initial study to support the determination of exact and decent location for grouper culture (Affan, 2010).

\section{Methods}

The study was conducted in December 2015 at Tual City, Dullah island, particularly in the Divur Bay with the coordinates between $5^{\circ} 26^{\prime}-5^{\circ} 26^{\prime}$ South Latitude and $132^{\circ} 41^{\prime}-132^{\circ}$ 49' East (Figure 1). Determining the ten points was referring purposively to the sampling station location physiographic (Nasution, 2001) with the help of Global Positioning System (GPS) for recording data of stations of the sea waters utilization (Ghani et. al., 2015; Hartoko and Alexander, 2009; Mukuan, 2013). To determine these utilization locations, it needs to consider several things including technical conditions such as water quality and coordinates therefore it could represent in terms of the ecosystem as well as the Divur Bay waters utilization. The time to collect water quality parameter samplings were conducted at 15:00-21:00 WIT and one time sampling in the water column.

Water quality parameters were measured directly in the field including temperature, clarity, salinity, $\mathrm{pH}$, depth, DO, and the current velocity. While the content of nitrate and phosphate sampling were performed and analyzed in the laboratory of Oceanography UPT Loka Marine Life Conservation LIPI Tual, Southeast Maluku. The results of water quality measurements were analyzed descriptively and compared to the sea water quality standard KepMen LH No. 51 of 2004 and literatures relating to mariculture.

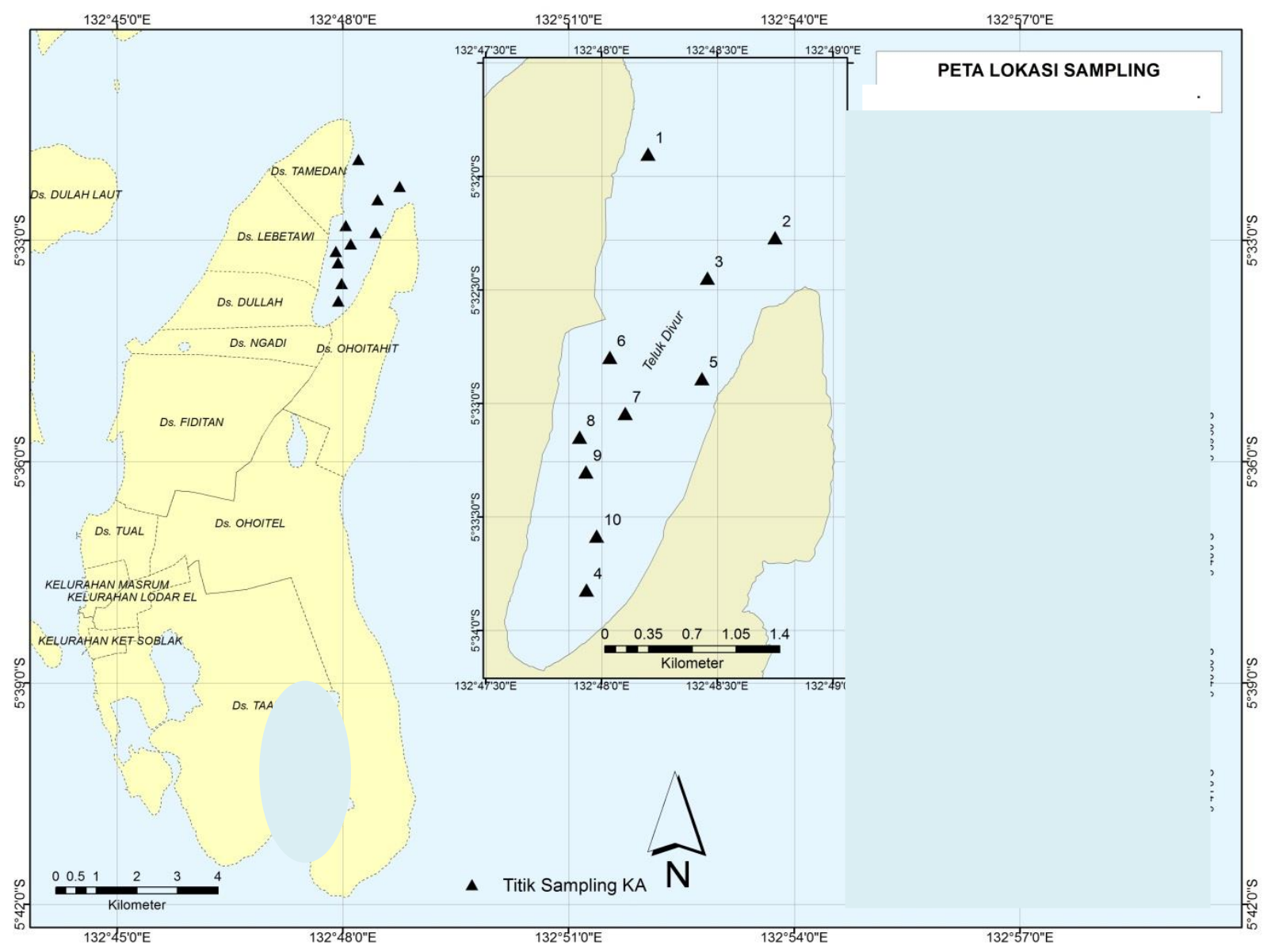

Figure 1. Research location 


\section{Result and Discussion}

The data of measurement result of waters quality parameters in Divur Bay and its analysis result were showed on Table 1 and 2 below.

\section{Temperature}

Water temperature in the Divur Bay had an average temperature of $30{ }^{\circ} \mathrm{C}$. The lowest temperature was $30^{\circ} \mathrm{C}$ at the station $7,8,9$, and 10 , while the highest temperature was 31 ${ }^{\circ} \mathrm{C}$ at the station $1,2,3,4,5$, and 6 . This temperature range was categorized normal temperature according to Mayunar et. al. (1995) which stated that the optimum temperature range for the cultivation of fish was 27-32 ${ }^{\circ} \mathrm{C}$ temperature as well as the criteria established by decree KepMen LH 2004 that is $25-32{ }^{\circ} \mathrm{C}$, with daily fluctuations of less than 1 ${ }^{\circ} \mathrm{C}$ which can be declared stable and feasible to attempt mariculture (Mudeng, et. al., 2015; Schaduw and Ngangi, 2015). The differences temperature was assumed due to differences of light intensity associated with the time of measurement (Schaduw and Ngangi, 2015). The temperature measurement at Stations 1, 2, $3,4,5$ and 6 was performed in the afternoon while the measurement at station 7, 8, 9 and 10 was carried out at night. The higher temperatures was in the afternoon than at night because there was still the heat of the day (Hutabarat, 2000). The optimal temperature at all stations in Divur Bay waters can improve ease of metabolism activity of organisme example groupers (Suhaimi, 2011).

\section{Clarity}

Waters clarity is closely related to incoming light penetration into the waters column due to the higher brightness of the light that penetrates the deeper waters (Schaduw and Ngangi, 2015) thus helping the food making process (Kangkan et. al., 2007). Clarity value of Divur Bay waters was measured at average of $6.69 \mathrm{~m}$. Station 2 had the lowest clarity value of $2.28 \mathrm{~m}$ while the station 5 had the highest clarity value of $7.86 \mathrm{~m}$. Differences in clarity values allegedly due to differences in the depth and time of measurements (Schaduw and Ngangi, 2015; Mukuan et. al., 2013), station 2 had the same clarity value and depth, while station 5 had the different clarity value with its depth. Clarity values were obtained by comparing it to the standard criteria of seawater for mariculture interests according to KepMenLH No 51 2004, therefore station 2 is not eligible for mariculture activities due to its clarity value which was less than $3 \mathrm{~m}$, whereas if the clarity value is greater than $3 \mathrm{~m}$ as at station $1,3,4,5,6,7,8,9$, and 10 , then it is eligible to marine aquaculture activities.

Table 1. Measurement result of waters quality parameters in Divur Bay

\begin{tabular}{cccccccccc}
\hline Stasion & Temperature & Clarity & Salinity & pH & $\begin{array}{l}\text { Current } \\
\text { velocity }\end{array}$ & Depth & Do & Phosphate & Nitrate \\
\hline 1 & 31 & 3.08 & 35 & 8.1 & 0.19 & 3.08 & 3.4 & 0.0109 & 0.0678 \\
2 & 31 & 2.28 & 35 & 8.1 & 0.16 & 2.28 & 3.2 & 0.0106 & 0.0767 \\
3 & 31 & 4.2 & 33 & 7.7 & 0.09 & 4.20 & 2.3 & 0.0016 & 0.0654 \\
4 & 31 & 6.69 & 34 & 7.9 & 0.20 & 18.27 & 3.3 & 0.0016 & 0.0229 \\
5 & 31 & 7.86 & 35 & 7.9 & 0.14 & 12.76 & 3.9 & 0.0043 & 0.0224 \\
6 & 31 & 6.65 & 34 & 7.9 & 0.06 & 15.95 & 4.8 & 0.0015 & 0.0088 \\
7 & 30 & 6.68 & 34 & 7.8 & 0.61 & 16.72 & 4.7 & 0.0219 & 0.0165 \\
8 & 30 & 6.17 & 34 & 7.7 & 0.15 & 12.48 & 4.6 & 0.0043 & 0.0147 \\
9 & 30 & 5.6 & 34 & 7.8 & 0.44 & 16.85 & 4.3 & 0.0070 & 0.0454 \\
10 & 30 & 6.53 & 35 & 7.8 & 0.47 & 18.58 & 3.2 & 0.0126 & 0.0076 \\
\hline
\end{tabular}

Table 2. Analysis result of waters quality parameters in Divur Bay

\begin{tabular}{llllll}
\hline Parameters & Unit & Min & Max & Average & Std \\
\hline Temperature & ${ }^{\circ} \mathrm{C}$ & 30 & 31 & 31 & 0,52 \\
Clarity & meter & 2,28 & 7,86 & 6,69 & 2,89 \\
Salinity & $\mathrm{mgL}^{-1}$ & 33 & 35 & 34 & 0,67 \\
pH & - & 7,7 & 8,11 & 8 & 0,19 \\
Velocity & $\mathrm{ms}^{-1}$ & 0,06 & 0,61 & 0,25 & 0,19 \\
Depth & $\mathrm{meter}^{-1}$ & 2,28 & 18,58 & 8 & 7,06 \\
DO & $\mathrm{mgL}^{-1}$ & 2,3 & 4,8 & 3,77 & 0,82 \\
Phosphate & $\mathrm{mgL}^{-1}$ & 0,0015 & 0,219 & 0,00763 & 0,01 \\
Nitrate & $\mathrm{mgL}^{-1}$ & 0,0767 & 0,0076 & 0,03482 & 0,03 \\
\hline
\end{tabular}


Salinity

The survival and growth of aquatic organisms are also affected by salinity. Appropriate salinity waters value range marine water according to the quality standards for grouper fish farming are 25-30 $\mathrm{mgL}^{-1}$ (KepMenLH 2004). The average salinity measured of Divur Bay was $34 \mathrm{mgL}^{-1}$, with the lowest salinity was $33 \mathrm{mgL}^{-1}$ at station 3 , and the highest salinity was $35 \mathrm{mgL}^{-1}$ at station 1,2 , 5 , and 10 . Salinity values of Divur Bay waters were relatively high. It was presumably because of the time of measurement, its waters was in a state of relatively low rainfall intensity and the Bay waters boundary was directly lead to the open sea therefore there are not much on the mainland (Gundo et. al., 2011). Salinity measurement values obtained showed that the salinity value supported the grouper mariculture, by comparing to the research results of Radiarta et. al., 2003 with a salinity range between $30-35 \mathrm{mgL}^{-1}$. This very small variation means Divur Bay waters salinity categorized homogeneous (Affan, 2010).

$p H$

The degree of acidity $(\mathrm{pH})$ of waters affects the fishes' growth and survival (Affan, 2011). The average $\mathrm{pH}$ measurement value which obtained was 8 . Station 1 and station 2 had the largest ph value which was 8.1. The lowest $\mathrm{pH}$ value was 7.7 at station 3 and station 8 . These values indicated that the water had alkaline characteristic, as sea water $\mathrm{pH}$ level value in general (Susana, 2009). In addition, the $\mathrm{pH}$ value is also an indication of water bodies disruption (Simanjuntak, 2007), because the higher $\mathrm{pH}$ value, the more easy-going metals accumulation (Wahab, 2005). Variations in $\mathrm{pH}$ values which were measured very small meant that the $\mathrm{pH}$ of the Divur Bay waters was very homogeneous. The range $\mathrm{pH}$ value measured at all stations in Divur Bay waters were still counted sea water quality standard range of KepMen LH No. 51 (2004) which is maximum of 8.5 .

\section{Current velocity}

Current is a factor that affects dissolved oxygen level in the water, carries dissolved and suspended particles, as well as contributes to the circulation of water. In grouper mariculture with KJA, current velocity plays a role in reducing biofouling on the nets (Affan, 2011). Current velocity measurement obtained an average value of $0.25 \mathrm{~ms}^{-1}$. The fastest current velocity value measured at the station 7 was $0,61 \mathrm{~ms}^{-1}$ and the most less current velocity value at the station 6 was 0,06 $\mathrm{ms}^{-1}$. By monitoring from its average current velocity, the Divur Bay waters were belongs to the slow current velocity within the $0-0.25 \mathrm{~ms}^{-1}$ (Sukendi et. al., 2013). Based on KepMen LH No. 51 (2004) sea water quality standards, the current velocity in Divur Bay sea water was very appropriate to the development of grouper mariculture ie $\geq 0.05 \mathrm{~ms}^{-1}$.

\section{The depth}

The variable that also becomes a determinant for successful grouper mariculture in KJA is the waters depth. The proper waters depth can avoid the damage nets due to puffer fish (Diodon sp) attack as pests, as well as the rest of food accumulation which remains in the bottom of the sea waters and leads to decreased the fishes' quality of life (Hartoko and Alexander, 2009; Ghani et. al., 2015). The deepest water was $18.58 \mathrm{~m}$ at station 10 and the shallowest was $2.28 \mathrm{~m}$ at station 2 with an average of $8 \mathrm{~m}$. The shallow waters in the Divur Bay were at stations 1,2 and 3. Seven other stations were conted to the category of waters with an appropriate depth to support the grouper mariculture development according to the categories defined by DKP (2002) which is 5-25 m.

\section{DO}

Variable of dissolved oxygen (DO) is the most critical variable in fish farming. Dissolved oxygen comes from the air diffusion and photosynthesis process. The content of DO in the water depends on the temperature, salinity and air pressure (Affan, 2011). The average $D O$ value obtained was $3.77 \mathrm{mgL}^{-1}$. The largest $\mathrm{DO}$ value was $4.8 \mathrm{mgL}^{-1}$ at the station 6 . While the smallest $\mathrm{DO}$ value was $2.3 \mathrm{mgL}^{-1}$ at the station 3. Dissolved oxygen concentration obtained was varied at each station, presumably because of the differences in depth and measurement time (Ghani et. al., 2015), the movement and mixing of water masses, as well as the daily cycle (Kangkan, et. al., 2007). Variations in the value of the measured DO smaller which means that the dissolved oxygen content is relatively homogeneous, allegedly caused by the influence of the movement of wind, temperature and salinity (Affan, 2010). When it was compared to the quality standard DO value suitable for cultivation, it should be greater than $5 \mathrm{mgL}^{-1}$ (KepMenLH No. 51 , 2004). In addition, according to the research of Bakosurtanal (1996) the DO value which is suitable for marine life ranges from 4 to more 
than $6 \mathrm{mgL}^{-1}$. Therefore the content of dissolved oxygen in Divur Bay, particularly at stations $6,7,8$ and 9 could still support the development of grouper mariculture.

\section{Phosphate}

Phosphate compounds which is contained in the water comes from soil erosion, weathering plants and effluent from animal (Affan, 2010). The content of phosphate in the water always changed every month allegedly due to the influence of the seasons such as rainy season which would reduce levels of phosphate in the waters as well as the influence of $\mathrm{pH}$ and temperature (Sukendi et. al, 2015). The average phosphate content in Divur Bay was $0.00763 \mathrm{mgL}^{-1}$. The largest phosphate value contained at the station 7 was $0.0219 \mathrm{mgL}^{-1}$ and the smallest was 0.0015 $\mathrm{mgL}^{-1}$ at station 6 . The phosphate levels which was suggested by KepMen LH No. 51 (2004) is $0.015 \mathrm{mgL}^{-1}$. According to the regulation, then from ten stations where were observed, only one station had exceeded phosphate levels. It can be concluded that the Divur Bay waters can support the development of grouper mariculture.

\section{Nitrate}

The average nitrate measured in Tual Town Divur Bay was $0.03482 \mathrm{mgL}^{-1}$. Station 2 was the station with the largest nitrate content of $0.0767 \mathrm{mgL}^{-1}$, while the station 10 was the station with the lowest nitrate content of 0.0076 $\mathrm{mgL}^{-1}$. Nitrate quality standards value according to KepMenLH no 512004 was below 0.008 $\mathrm{mgL}^{-1}$ therefore the distribution of nitrates in the waters of Divur Bay measured average above the threshold and less support for the development of aquaculture, but not toxic to aquatic organisms as it is still within safe enough for marine organisms (Sukendi et. al., 2013).

Of the ten stations studied, water quality parameters that meet the feasibility for grouper mariculture are stations 6,8 and 9 because of the eight parameters observed only one parameter is nitrate that does not meet the quality standards of water quality.

\section{Conclusion}

Tual Town Divur Bay water quality parameters which were measured at ten stations in this study among others temperature, brightness, salinity, $\mathrm{pH}$, current velocity, depth, dissolved oxygen (DO), phosphate, and nitrate. Parameter measurement results which were obtained from this research were temperature 30 to $31 \mathrm{oC}$, brightness 2.28 to $7.86 \mathrm{~m}, 33$ to $35 \mathrm{mgL}-1$ salinity, $\mathrm{pH} 7.7$ to 8.1 , the current velocity 0.06 to $0.617 \mathrm{~m} \mathrm{/} \mathrm{s}$, DO 3.77 to $4.8 \mathrm{mgL}-1$, phosphate 0.0015 to $0.0219 \mathrm{mgL}-1$, and nitrate 0.0076 to $0.0767 \mathrm{mgL}-1$. Comparing to the regulation of KepMenLH no. 51 (2004) and the previous researches, it was concluded that the current velocity, depth, temperature, salinity, brightness, $\mathrm{pH}$, and DO would support mariculture development efforts. The phosphates and nitrates values which were supporting parameters obtained values above the quality standard, therefore it supported less the grouper mariculture business development in the Tual Town Divur Bay.

\section{References}

Affan, J.M., 2010. Analisis potensi sumberdaya laut dan kualitas perairan berdasarkan parameter fisika dan kimia di pantai timur Kabupaten Bangka Tengah. Spektra 10 (2) : 99-113.

Affan, J.M. 2011. Seleksi lokasi pengembangan budidaya dalam keramba jaring apung (KJA) berdasarkan faktor lingkungan dan kualitas air di perairan pantai timur Kabupaten Bangka Tengah. Jurnal Sains MIPA 17 (3) : 99-106.

Asaad, A.I., Makmur, Rachmansyah, Undu, M.C. 2010. Analisis faktor kondisi kontinuitas budidaya keramba jaring apung di Teluk Lampung. Prosiding Forum Inovasi Teknologi Akuakultur : 1157-1163.

[BPS] Badan Pusat Statistik Maluku Tenggara. 2015. Kota Tual dalam angka 2015. Tual (ID): Badan Pusat Statistik.

Bakosurtanal. 1996. Pengembangan prototipe wilayah pesisir dan kelautan Kupang, Nusa Tenggara Timur. Pusat Bina Aplikasi Inderaja dan Sistem Informasi Geografis. Cibinong.

Departemen Kelautan dan Perikanan, 2002. Modul sosialisasi dan orientasi penataan ruang, laut, pesisir dan pulau-pulau kecil. Ditjen Pesisir dan Pulau-Pulau Kecil. Direktorat Tata Ruang Laut, Pesisir dan Pulau-Pulau Kecil. Jakarta.

Ghani, A., Hartoko, A., Wisnu, R. 2015. Analisa kesesuaian lahan perairan Pulau Pari Kepulauan Seribu sebagai lahan 
budidaya ikan kerapu (Epinephelus sp) pada keramba jaring apung dengan menggunakan aplikasi SIG. Journal of Aquaculture Management and Technology 4 (1) : 54- 61.

Gundo, C., Arfiati, S., Harafat, N., Kaunang, T.D. 2011. Analisa parameter oceanografi di lokasi pengembangan Euchema spinosum Pulau Nain Kabupaten Minahasa Utara. Jurnal IImu Kelautan $16:$ 193-198.

Hartoko, A., Alexander, K. 2009. Spatial modelling for marine culture site selection based on ecosystem parameters at Kupang Bay, East Nusa Tenggara-Indonesia. International Journal of Remote Sensing and Earth Science 6 (3) :57- 64.

Hartoko, A., Helmi, M. 2004. Development of digital multilayer ecological model for Padang coastal water (west sumatera). Journal of Coastal Development 7 (3) : 129-136.

Hishamunda, N., Neil, B.R., Pedro, B., Wilfredo, G.Y. 2009. Commercial aquaculture in Southeast Asia: some policy lessons. Food Policy 34. 102-107.

Hishamunda, N., Ridler, N. 2006. Farming fish for profits:a small step towards food security in sub-Saharan Africa. Food Policy 31 (5) : 401- 414.

Hutabarat, S. 2000. Peranan kondisi oceanografi terhadap perubahan iklim, produktivitas dan distribusi biota laut. UNDIP. Semarang.

IFPRI. 2003. Fish to 2020: supply and demand in changing markets. In: Delgado, C., Meijer, S., Rosegrant, M.(Eds), International Food Policy Research (IFPRI). Washington DC.

Kangkan, A.L., Hartoko, Suminto. 2007. Studi penentuan lokasi untuk pengembangan budidaya laut berdasarkan parameter fisika, kimia, dan biologi di Teluk Kupang, Nusa Tenggara Timur. Jurnal Pasir Laut 3 (1) :76-93.

Keputusan Menteri Negara Lingkungan Hidup. 2004. Baku mutu air laut. Keputusan Meneg.KLH No.51 Tahun 2004, tanggal 8 April 2004. Jakarta.
Direktorat Jenderal Perikanan Budidaya. 2011. Profil ikan kerapu Indonesia. Direktorat Produksi. Jakarta.

Kusumaningrum, I. 2015. Coast environment conservation by home scale grouper culture in Pecaron-Situbondo. Journal Aquaculture Research and Development $6(4): 330$.

Mayunar, Purba, B., Imanto, P.T. 1995. Pemilihan lokasi untuk budidaya ikan laut. Prosiding Temu Usaha Pemasyarakatan Teknologi Keramba Jaring Apung bagi Budidaya Laut. Pusat Penelitian dan Pengembangan Perikanan. Kerjasama antara Badan Penelitian dan Pengembangan Pertanian-Forum Komunikasi Penelitian dan Pengembangan Agribisnis (FKKPA). Jakarta. 179-187.

Mudeng, J.D., Edwin, L.A.N., Rompas, R.J. 2015. Identifikasi parameter kualitas air untuk kepentingan marikultur di Kabupaten Kepulauan Sangihe Provinsi Sulawesi Utara. Jurnal Budidaya Perairan 3 (1) : 141-148.

Mukuan, E.M.R., Sukoso, Arfiati, D., Kepel, R.Ch., 2013. Fish farming development potency with floating fish cage system in Amurang District, South Minahasa Regency, Indonesia. IOSR Journal of Environmental Science, Toxicology and Food Technology 5 (2) : 5-11.

Mustafa, A., Radiarta, I.N., Rachmansyah. 2011. Profil dan kesesuaian lahan akuakultur mendukung minapolitan. Badan Penelitian dan Pengembangan Kelautan dan Perikanan Pusat Penelitian dan Pengembangan Perikanan Budidaya. Jakarta.

Nasution, S. 2001. Metode Research (Penelitian IImiah). Penerbit Bumi Aksara. Jakarta.

Radiarta, I.Ny., Wardoyo, S.E., Priyono, B., Praseno. 2003. Aplikasi sistem informasi geografis untuk penentuan lokasi pengembangan budidaya laut di Teluk Ekas, Nusa Tenggara Barat. Jurnal Penelitian Perikanan Indonesia 9 (1) : 67-71.

Raharjo, S. 2008. Pemilihan lokasi budidaya rumput laut. Departemen Kelautan dan Perikanan Direktorat Jenderal Perikanan 
Budidaya, Balai Budidaya Air Payau. Takalar.

Schaduw, J.N.W., Ngangi, E. 2015. Karakterisasi lingkungan perairan Teluk Talengen Kabupaten Kepulauan Sangihe sebagai kawasan budidaya rumput laut Kappaphycus alvarezii. Budidaya Perairan 3 (2) : 29-44.

Simanjuntak, M. 2007. Oksigen terlarut dan apparent oxygen utilization di Perairan Teluk Klabat, Pulau Bangka. IImu Kelautan 12 (2) : 59-66.

Sugama, K., Danakusumah, E., Eda, H. 1986. Effect of feeding frequency on the growth of estuary grouper, Epinephelus tauvina cultured in floating net cages.Sci.Rep.Mar.Rep.of China.

Suhaimi, RA, Hasnawi, Fahrur M. 2011. Pemilihan lokasi untuk budidaya ikan kerapu dalam keramba jaring apung di Teluk Mallasaro, Kabupaten Jeneponto,Provinsi Sulawesi Selatan.
Sukendi, Thamrin, Ulfa, M. 2013. Carrying capacity of Mantang Sub District Waters Bintan District, Riau Islands Province for aquaculture activities in floating net cages. International Journal of Science and Research (IJSR) 4 (3) : 790- 796.

Susana, T. 2009. Tingkat keasaman $(\mathrm{pH})$ dan oksiegen terlarut sebagai indikator kualitas perairan sekitar muara sungai Cisadane. Jurnal Teknologi Lingkungan $5: 33-39$.

Wahab, A.W. 2005. 2005. Analisis kandungan logam berat timbal dan seng di sekitar perairan pelabuhan Pare-Pare dengan metode adisi standar. Marina Chemica Acta : 21-24.

Wijkstrom, U. 2003. Short and long term consumption of fish. Veterinary Research Communication 27 (1) : 461- 468.

Yulianto, I., Hammer, C., Wiryawan, B., Palm, H.W. 2015. Potential and risk of grouper (Epinephelus spp., Epinephelidae) stock enhancement in Indonesia. Journal of coastal zone management 18 (1) : 1-9. 